\title{
International Law and Crisis Narratives after the COVID-19 Pandemic
}

\author{
Catherine Kessedjian
}

Increased cooperation is the way forward. ${ }^{1}$

To start, I would like to challenge the topic that the editors of the volume have imagined. I would like to challenge the use of two concepts: "crisis" and "after". ${ }^{2}$

Let's start with "after". We would be better off if we recognized that the pandemic is still here, that we must learn to live with it and that, even if we overcome COVID-19, there will be other viruses or similar infectious diseases that we will need to overcome. Therefore, it does not help to think about international law through the concepts of "before" and "after". We are in the middle of it and it will stay with us in one form or another for many years to come. Indeed, we could also argue that the pandemic ${ }^{3}$ started much before the end

1 This chapter was written in large parts in the summer of 2020. As I was putting a final note to this short contribution, the passing of Justice Ruth Bader Ginsburg struck a very sad note on the day. It is quite fitting to recall her words during a speech she gave to the International Academy of Comparative Law in 2010: 'I nonetheless believe the U.S. Supreme Court will continue to accord "a decent Respect to the Opinions of [Human]kind" as a matter of comity and in a spirit of humility. Comity, because projects vital to our well being ... require trust and cooperation of nations the world over. And humility because, in Justice O'Connor's words: "Other legal systems continue to innovate, to experiment, and to find ... solutions to the new legal problems that arise each day, [solutions] from which we can learn and benefit."' <https://aidc-iacl.org/ruth-bader-ginsburg-a-decent-respect-to-the-opinionsof-humankind-the-value-of-a-comparative-perspective-in-constitutional-adjudication/> accessed 18 September 2020.

2 Erri de Luca in his book Impossible (which I read in the translation in French) has a humoristic way to encourage us all to use precise language: 'La langue est un système d'échange comme la monnaie. La loi punit ceux qui impriment des faux billets, mais elle laisse courir ceux qui écoulent des mots erronés'. Erri de Luca, Impossible (Gallimard 2019) 113.

3 As I revise this text during the editorial process in March 2021, an author proposed the concept of "syndemic" instead of "pandemic" to show that many aspects of our lives were turned

(C) CATHERINE KESSEDJIAN, 2022 | DOI:10.1163/9789004472365_014

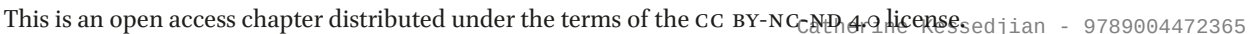
Downloaded from Brill.come4/26/2023 02:03:29PM 
of 2019, but we were simply blind to it. This has major consequences as to what kind of international legal regime we need.

The above bears an immediate consequence on the use of the concept of "crisis". I will not offer a pedantic analysis of the medical origins of the concept; neither will I dwell on the numerous other usages that have developed over time. However, one factor is essential: whether in economy, psychology or theatre, a crisis is a temporary phenomenon, not permanent, which is overcome after a short period of time and after proper measures are taken. What we are living through is here to stay, it is permanent. Hence it is not a "crisis". We are in a transformational period. We need to conduct a serious analysis of the permanency of the transformation before we can propose useful cures for the illnesses that the international system is suffering.

What are the consequences of these premises? First, the Covid-19 pandemic cannot be overcome only by temporary measures. Because it is here to stay, it changes the fundamental paradigm upon which we have regulated the world until now. Second, it creates a world of uncertainty. ${ }^{4}$ How are we to define the rules of the game when everything is uncertain and can be turned upside down in a very short period of time? Third, it seems to upset all previous certainties. Can we build on previous certainties anymore? Can we build new certainties upon which international law may be grounded? A lot has been said about "the return of the State". But this "return" is a dramatic step in the dark past that, in my view, has shown its complete lack of cogency. Borders have been rejuvenated as if the only way to fight the pandemic was to isolate each territory and its population against its neighbours. What about world governance? The silence on this issue is deafening.

I will try to develop these ideas throughout the rest of this paper.

General lockdown or confinement of millions of people is an antiquated measure. It may have been necessary because of the total unpreparedness of most (if not all) of the authorities around the world. It is very important that we

upside down because of the virus. Richard Horton, "Offline: COVID-19 is not a pandemic", (2020) 396 Lancet 874 .

4 See e.g. Jean-Luc Nancy, La peau fragile du monde (Galilée, 2020); Ilaria Gaspari, 'Vivre dans les limites de l'incertitude' La conversation mondiale, (France Culture, 28 August 2020) <https:// www.franceculture.fr/societe/ilaria-gaspari-vivre-dans-les-limites-de-lincertitude $>$ accessed 28 August 2020 . 
analyse properly the exact reasons that may have justified such a measure at the time, because we certainly want to avoid a renewal of such measures which have long-term effects on the wellbeing of the people at large, on the social fabric of our communities, on culture and on education of the youth. ${ }^{5}$ There are, on the positive side, some advantages that have come from the lockdown: less environmental stress (but not enough to really stop destroying planet earth), some additional solidarity among neighbours (although not everywhere) and some realization that true values matter (although many would debate the meaning of "true values").

If we take for granted (for the sake of discussion) that we do not want to live through a new lockdown and do not accept massive additional deaths ${ }^{6}$ until a vaccine is available, then what measures should be taken and how should they be implemented?

Unless I have missed something in the discourse in this area, the measures that need to be implemented to achieve the two goals mentioned above are (1) identify the people that are infected with the disease, and (2) require them to respect a quarantine (the exact number of days that an infected person must isolate is not 40 days, but may range from one week to 14 days, depending on who has the final decision on this matter). This identification renders compulsory a certain amount of surveillance of the population, with or without electronic means, as the recent discussions have shown in many countries, unless we might count on each citizen's sense of responsibility towards the community. The surveillance must be made all over the world. Hence increased cooperation is necessary. But that cooperation must be made via really independent people and bodies, and we cannot rely on the State only. Indeed, it would be all too easy for a State to use sanitary reasons to unduly limit people's freedom to an extent not absolutely necessary to monitor the sanitary situation. Can we rely on courts to provide a proper check and balance for States' actions? As much as I would like to answer positively, we have had too many examples of lack of independence of judges, that I would propose that judicial control won't be enough in many instances. We must also use mechanisms of civil society to monitor the strict

5 Education for young people is one of the dark corners of the pandemic. Numbers are frightening. According to some analyses, millions of children will not return to school soon, and many will never return. Most of these children live in poor areas. The pandemic is definitely aggravating the social, economic, and medical discrepancies between the poor and the well-to-do.

6 The balancing act on this matter is a very delicate one. 
proportionality of the measures taken, alert the competent authorities when measures are going too far from the initial goal and monitor the changes that must be implemented.

Internationally, we need an independent institution, such as the wHo, but with mixed representations: State representatives, independent experts, civil society. International cooperation is crucial in order for the system to work, particularly when one thinks of mobility (see below). The new wHO should be much more visible and should be given additional powers, notably for coordination of research, cooperation in the implementation of necessary measures and the like. Common efforts should be put into the development of secured tests, that are easy to administer and whose results are fast to get. Travel may be made conditional on the showing of such tests being negative. We are used to all kinds of formalities when travelling. These formalities are limiting one's freedom for sure. But if the wellbeing of millions of people is at stake, it does not seem too much of a price to pay to add one more health formality. Cooperation across borders is crucial to achieve this goal. Tests must be "recognized" from one country to the other. That will be easier if coordination of research and production has been made ex ante. People returning positive tests will have to self-isolate for a certain period of time. If self-isolation entails adverse consequences on workrelated activities, collective measures should be put into place to alleviate the consequences for the person at stake. Those of us who are old enough to hold in their wallet an "international vaccine passport" know that this may be revived with additional requirements. It is somewhat burdensome but, again, it is proportional if the measure has the power to save lives. What I just said for testing is true for all health-related issues. They must not be left to each State separately, but should be decided and implemented in coordination as a global necessity. If we achieve this for health issues, we will be able to use the template for other global issues such as climate change, water, agriculture, and each additional issue that impacts the wellbeing of humans and other living creatures.

Mobility - The Archetype of Globalization

Who would have predicted that, in the first quarter of the 21st century, international mobility would be entirely suppressed and that we would have to rely on electronic communications to keep in touch with people around the globe, whether for personal or professional reasons? Orwell did not think in those 
terms and Saramago was concerned about the moral values that are at stake when an entire population becomes blind, but one person. ${ }^{7}$

Globalization, as we have known it during the second half of the 2oth century and the first quarter of the 21st, was built on mobility. Indeed, an organization such as the European Union has been entirely constructed around mobility. It is true that mobility was first and foremost mobility of goods ${ }^{8}$ and, only gradually, of persons. ${ }^{9}$ It is also true that capital mobility has not been stopped at all during the pandemic. Circulation of goods has continued and was lessened by two factors: the decrease in production because of the labour force being prevented, sometimes, from reaching industries' premises; the decrease in available transportation vehicles also for lack or decrease in the labour force. Some will rejoice about the "halt" to globalization that the lockdown has entailed. It is true that the lockdown has shown how necessary local production is. But we should not have needed a lockdown to administer that proof. Indeed, local production of essential goods should have always been at the forefront of public policies. Instead, local production was, very often, reserved to luxury goods resulting in one of the most extraordinary oxymorons.

Mobility of goods may still be necessary as some countries may have a "savoir-faire" not shared by others, or benefit from climate conditions that allow certain productions that are impossible under a different climate. So, globalization may still be useful but should be regulated in a global way, outside the model of competition, within a model of cooperation and reciprocal help. It is quite ironic that we need a virus to convince us that we all live on the same small planet and that we are all interdependent.

Consequently, physical mobility should be more reasoned and not be the alpha and omega of the dominant social and economic model. We all know that in order for forced migration to stop, we should trigger a safer environment in every and all countries and on all fronts. A child born in January 2020 will start her life in a small cocoon of parents, close neighbours, and a few friends. If she is lucky, she will see her extended family and more of her friends via the internet. Mobility may not be as crucial for that child as it was for the

7 José Saramago, Ensaio sobre a Cegueira (1995), (Geneviève Leibrich tr, L'aveuglement, Seuil, 1997). It is not fortuitous that the lead character in the book, not being contaminated by the disease, is a woman. See the discussions, during the confinement, when some have noted that countries that apparently dealt best with the pandemic have governments led by women.

8 Mobility of goods is many centuries old and not the prerogative of the 2oth century. At best, there was a major acceleration of the phenomenon after the Second World War.

9 For persons, mobility is a very ambiguous phenomenon: the poor have no choice but to risk their lives by moving; the rich had all facilities to move around as they please; the middle class enjoyed mass tourism and easy mobility for pleasure or work. 
generations following Second World War. And it should not be considered as a regression that we are prevented from travelling.

\section{Global Governance and Law of Proximity}

From the above, I conclude that we have, more than ever before, a need for global governance, but that what we call in private international law "the law of proximity" is still the level at which we should think of the law for human beings. This is not new, of course. I do not remember who invented the concept "glocal" i.e. "think global and act local". I argue that this is what we should have done a long time ago and it is about time to implement it.

Global governance should follow a cooperative/collaborative philosophy among States, other entities, and individuals alike. As I argued elsewhere, the competition paradigm, under which we have lived for most of the 2oth and the beginning of the 21st centuries, has killed human values of solidarity and empathy ${ }^{10}$ without which any society is unbearable. Every day we are given tragic examples of the lack of solidarity. How long are we going to continue along the same road? Well-conceived global governance will allow for the just and equitable allocation of raw materials, global resources (particularly water), energy and the like. Global governance will prevent conflicts, decide which communities need help and allocate funds towards general welfare. Global governance will mitigate the consequences of capitalism, if capitalism is maintained as the economic model. ${ }^{11}$ Global governance will decide the amount that each human being has the right to receive, what some call a "universal minimum wage" (UMW), how it is to be calculated and paid, and what are the conditions (if any) under which the UMw will be distributed. Global

10 The difference between empathy and sympathy is quite important to remember: e.g. if you saw somebody who fell into a well, sympathy would make you jump; empathy would make you call the rescue ward or go and get a ladder.

11 Many, today, express doubts that capitalism, as we have known it in the past twenty years at least, could survive. There is also a trend among some multinational corporations according which shareholders' interests should not be the only focus for corporations. See for example the declaration of the Business Roundtable of 19 August 2019 that focuses on stakeholders rather than shareholders. But a contrary trend was the focus of headlines in France on 10 September 2020 announcing that some corporations had distributed everincreased dividends during the height of the pandemic, above the level of their benefits. And the recent (February 2021) firing of Danone's CEO to please minority shareholders who complained, for not receiving enough dividends, is also a testimony of a battle that is still on going. 
governance will also allow sharing scientific discoveries in a way that encourages innovation but does not make it dependent on the wellbeing of others. The current pandemic, with its fierce competition for the creation of a vaccine, is a pitiful example at play of the worst sides of human greed. In sum, global governance will define general principles of cooperation and complementarity. The rest will be decided at local level.

A general principle of law has been developed in private international law called "the principle of proximity", which requires that among all the laws potentially applicable to and all the courts potentially competent for a certain matter, it is always preferable to choose the law or the court that presents the closest connection with the matter and the persons at stake. The principle of proximity is in line with the principle of subsidiarity, according to which legislation and regulation must always be decided at the level that is closest to the citizen for more efficiency and acceptability.

The law of proximity has also the advantage that citizens may choose to be regulated by certain norms specifically crafted for them, by them, provided they comply with the overall goals and values of the community at large and do not overstep the legitimate interests of their neighbours. The balance is a delicate one to achieve, but this is the condition upon which we will continue to enjoy dignity and serenity in our lives.

In order to achieve these goals, we need urgent reform of the current governance of most (if not all) international institutions. Checks and balances must be put in place so that an inclusive governance, acceptable for all, sets the proper policies for global issues, without which we will continue to suffer through the chaotic rules that a CoviD-19-like pandemic has triggered. 